\title{
Contraindications to Breastfeeding - Current Issues at the Border Between Myth and Reality
}

Ana Maria Alexandra STANESCU', Alexandra TOTAN'', Daniela MIRCESCU', Ioana Veronica GRAJDEANU', Bogdan SERBAN', Ovidiu Gabriel BRATU ${ }^{1,2}$, Camelia Cristina DIACONU ${ }^{1,3}$

\begin{abstract}
Breast milk is recommended as an optimal and exclusive source of early nutrition for all infants from birth to at least 6 months of age. Despite all the benefits of breastfeeding, there are situations where breastfeeding is contraindicated. There are differences of opinion regarding the contraindications of breastfeeding, the current research bringing more knowledge in this area. It is important to know the differences of opinion for the correct approach of the breastfeeding patient.
\end{abstract}

Keywords: breastfeeding, benefits, contraindications.

\section{Rezumat}

Laptele matern este recomandat ca sursă optimă și exclusivă de nutriție timpurie pentru toți sugarii de la naștere până la vârsta de cel puțin 6 luni. În ciuda tuturor beneficiilor alăptării, sunt situații în care este contraindicată alăptarea. Există diferențe de opinie în ceea ce privește contraindicațiile alăptării, cercetările actuale aducând un plus de cunoștințe în acest domeniu. Este importantă cunoașterea diferențelor de opinie pentru abordarea corectă a pacientei care alăptează.

Cuvinte cheie: alăptarea, beneficii, contraindicații.

\section{INTRODUCTION}

Breastfeeding is widely recognized as the normal and unmatched method for feeding infants. Breast milk is recommended as an optimal and exclusive source of early nutrition for all infants from birth to at least 6 months, being crucial for optimal development ${ }^{1}$. Breastfeeding continues to be an important part of the diet until the baby is at least two years old.

Milk is produced following several stages that begin before the baby is born. Milk production is regulated by

${ }^{\prime}$ "Carol Davila" University of Medicine and Pharmacy, Bucharest, Romania

${ }^{2}$ Department of Urology, Emergency University Central Military

Hospital, Bucharest, Romania

${ }^{3}$ Clinical Emergency Hospital, Bucharest, Romania the maternal hypothalamus and the hormones derived from the pituitary gland (mainly oxytocin and prolactin are hormones involved in milk production $)^{2}$.

The first milk is colostrum which generally appears after labor, but in some women, pre-colostrum may occur before the postpartum stage. Colostrum, although low in lactose, is high in protein, sodium and immunoglobulins; later, after 30-40 hours, the composition changes with increasing volume, becoming richer in lactose and diluting other constituents ${ }^{3}$. Colostrum may represent the first immunization of the child be-

\section{Corresponding author.}

Ana Maria Alexandra Stanescu, „Carol Davila" University of Medicine and Pharmacy, 050474, Bucharest, Romania. E-mail: alexandrazotta@yahoo.com 
cause it produces mucosal immunity in the gastrointestinal tract through secretory IgA, IgM and IgG; these vital immunoglobulins provide barrier protection to the intestine and also play a vital role in the fight against germs.

To successfully initiate breastfeeding, it is necessary to create a connection between the mother and the newborn, which is done by skin-to-skin contact between the mother and the newborn within the first two hours after birth ${ }^{4,5}$. Breastfeeding is a natural process, however the mother needs support and education from breastfeeding consultants or experienced nurses to properly position and support the newborn at the breast ${ }^{6,7}$. Breastfeeding is maintained and regulated autonomously by sucking the baby and emptying the breast.

Milk contains the microbiota such as Bifidobacterium and Lactobacillus and this together with the oligosaccharides confer anti-bacterial activity on the intestine and lead to the synthesis of essential nutrients such as vitamin B12, B6, folate and vitamin $\mathrm{K}^{8}$. Another component, lactoferrin, will act by increasing the absorption of iron and preventing its degradation by bacteria, conferring an immune protective action against bacterial, viral, fungal and parasitic infections ${ }^{9,10}$.

Other benefits of breastfeeding include: lowering the risk of upper respiratory tract infections, lowering the risk of diarrhea in newborns, developing asthma, allergies, obesity and type 1 diabetes ${ }^{11}$. From another point of view, breastfeeding represents a financial economic variant compared to the expensive milk powder formulas.

Maternal factors such as pain, anxiety and emotional instability must be addressed before and after birth ${ }^{12,13}$.

The use of medicines should be addressed especially to the breastfeeding mother. Some studies show that women take more medications during breastfeeding compared to pregnancy. It is necessary to advise and find alternative ways to prevent ending breastfeeding ${ }^{14}$.

Despite all the benefits of breastfeeding, there are situations where breastfeeding is contraindicated ${ }^{15}$. It is very important to know these situations in order to be able to properly balance the risk-benefit ratio.

\section{MEDICATION}

The effects of medication during pregnancy and lactation are not sufficiently studied for many products available on the market, as it is difficult to quantify the risk of transmission through breast milk to the baby.
The European summary of product characteristics uses the following phrase "the use of $90 \%$ of medicines is restricted both during pregnancy and during breast-feeding, despite the lack of information to support such indications" to avoid possible litigation ${ }^{16}$. This phrase can lead to cessation of breastfeeding in mothers who use medications, sometimes well-founded, other times only because of excessive caution.

Although most medicines pass into breast milk, the side effects are few and most often not causal. Adverse effects are most commonly present in the first two months of breastfeeding (exclusive or mixed) ${ }^{17,18}$.

In the absence of clinical studies, the assessment of the risk of lactation following drug administration is pharmacokinetic, it is possible to pass the drug through breast milk to infants when its half-life is short, the binding of maternal plasma proteins is high, biochemically the characteristics of the drug lead to a low ratio. from milk to plasma, and the absorption of the babyss intestine is slow, resulting in poor bioavailability ${ }^{19}$. The upper limit of safety transfer from mother plasma to breast milk is $10 \%$ of the dose administered to the mother, but cases exceeding $1 \%$ of the dose administered to the mother are rare ${ }^{19}$. Assessing the safety profile of a drug in breastfeeding women requires investments by health professionals in terms of specific scientific knowledge and empathic approach.

Feldman-Winter et al. showed that in 2014 only $57 \%$ of young pediatricians considered that mothers could successfully breastfeed and only $50 \%$ considered that the benefits of breastfeeding outweigh the difficul$\operatorname{ties}^{20}$. It is very important for the correct counseling of the mothers by the specialists in the field.

\section{CONTRACEPTION}

Although, in general, breastfeeding women have lactational amenorrhea and ovulation is unlikely, however, it may be necessary to use contraceptive methods by mothers who want to make sure they will not become pregnant ${ }^{21,22}$.

Contraceptive methods such as diaphragm and condom are safe to use by the breastfeeding mother, they do not influence milk production.

From the point of view of hormonal contraception, it is not completely contraindicated. Combined hormonal contraceptives are recommended to use, initially those with the lowest dose of estrogen and to follow the lactation because there is a risk of decreasing milk flow and even stopping lactation. Hormonal contraceptives 
with progesterone generally do not affect milk intake ${ }^{23}$. The safety of a contraceptive method should be determined based on, the breastfeeding phase, increased thrombotic risk in the postpartum period and the womanıs lifestyle, especially in women who have low milk production and those in the first two months postpartum. Both combined hormonal contraception and progesterone contraception can be safely used after the first 42 days postpartum ${ }^{24}$.

\section{CONTRAST SUBSTANCES}

Contrary to wrong opinions, radiation does not affect the quality of breast milk or the health of the breastfed baby. In contrast, iodine or gadolinium-based contrast agents may pass into breast milk. It is recommended to stop breastfeeding 24 to 48 hours after exposure of the mother to the contrast substance. The American College of Radiology has shown that intravenous administration of the mother's iodinated X-ray contrast agent will reach infants $<0.01 \%$, and in the case of gadolinium contrast agent $<0.0004 \%{ }^{25}$.

\section{BREASTFEEDING DURING PREGNANCY}

Even in ancient Rome, women were discouraged from breastfeeding if they became pregnant (both medically and culturally), considering that breastfeeding during pregnancy would have harmful effects on women's health ${ }^{26}$. In current medicine, some physicians claim that breastfeeding during pregnancy leads to maternal malnutrition, slowing fetal growth, premature birth, spontaneous abortion, reduced quality and / or quantity of breast milk, but also slowing the growth of the breastfed baby.

In the literature, there is no evidence to attest the risk of spontaneous abortion, premature birth or intrauterine growth restriction in women in developed countries. In women in developing countries where mother's nutrition may be suboptimal, there is a risk of affecting the composition of postpartum breast milk and the growth of the newborn ${ }^{27}$.

However, situations with risk of preterm birth such as: previous preterm birth, multiple gestation, intrauterine growth retardation should be considered. On the other hand, the age of the baby should be taken into account, after the age of 6 months most likely the diversification has begun, the feeding being not exclusively by breastfeeding, and also at this age the baby may be weaned.

\section{BREAST CANCER BEFORE PREGNANCY}

Earlier breast cancer is not a contraindication to breastfeeding, instead it may be an impediment due to the modified anatomy of the mammary gland and the impact on the aesthetic aspect of the body, making breastfeeding more difficult and shorter breastfeeding duration $^{28,29}$.

It is considered that giving birth and breastfeeding would increase the protection against breast cancer, the risk of developing breast cancer decreases by $4.3 \%$ for every 12 months of breastfeeding and in the case of each birth it decreases by 7\%30,31. Lambertini et al. they did not find differences in the survival of breast cancer in the women who subsequently gave birth in comparison to those who did not give birth ${ }^{32}$.

\section{BREAST AUGMENTATION AND REDUCTION MAMMOPLASTY}

Augmentation mammoplasty is a surgical procedure that increases the size of the breast by introducing breast implants beneath the breast tissue or thoracic muscles ${ }^{33}$. This procedure is used for breast reconstruction following breast cancer or to improve the physical appearance. Breastfeeding is not usually contraindicated. Roberts et al. showed a lower breastfeeding rate in $79 \%$ of women with breast implants compared to $89 \%$ without breast implants and in the first month breastfeeding exclusively to $54 \%$ of women with breast implants compared to $80 \%$ in women without breast implants ${ }^{34}$.

Breast reduction is done by removing excess breast fat, glandular tissue and skin. In general, this procedure is only used to improve the appearance and eliminate discomfort in the case of very large breasts. When performing the procedure, certain surgical techniques are used to maintain breastfeeding capacity. It seems that preserving the subarachnoid parenchyma increases the subsequent chances of breastfeeding, when the subarachnoid parenchyma was not kept, only $4 \%$ of women were able to breastfeed ${ }^{35}$. Some studies have shown that women following reduction mammoplasty discontinued exclusive breastfeeding after an average duration of only 5 days and had an exclusively breastfeeding rate at 4 months after birth of $4 \%$ compared to control $22 \%{ }^{36}$. 


\section{PROLACTINOMA}

Prolactinoma (pituitary tumor) is one of the most common causes of excess prolactin leading to hypogonadism, infertility and galactorrhea.

Opinions on the influence of breastfeeding in the case of a pre-existing prolactinoma are divided. A survey of 468 doctors showed that $47 \%$ of them would allow unrestricted breastfeeding, 28\% would allow breastfeeding only by patients with microprolactinomas and $25 \%$ would not recommend breastfeeding at $\mathrm{all}^{37}$.

Dopamine agonists are used in the treatment of hyperprolactinaemia, they improve fertility in $90 \%$ of cases and are discontinued once pregnancy is confirmed. Microprolactinomas have a risk of increase during pregnancy of $2-3 \%$ and macroprolactinomas of 20-30\% ${ }^{38}$. Breastfeeding does not influence tumor growth but treatment with dopamine agonists should not be resumed during breastfeeding.

\section{HUMAN IMMUNODEFICIENCY VIRUS (HIV) INFECTION IN THE MOTHER}

Until now, it was considered that HIV can be transmitted from the mother not only during pregnancy or during birth but also through breastfeeding. Research has shown that the administration of antiretroviral drugs to mothers and babies can significantly reduce the risk of HIV transmission through breastfeeding ${ }^{39,40}$. The rate of postnatal transmission of HIV from mother to fetus when the mother is receiving antiretroviral treatment was estimated at $3.5 \%$ at 6 months and $4.2 \%$ at 12 months ${ }^{41,42}$. The World Health Organization recommends that the mother should take antiretroviral treatment before birth, by reducing viremia the risk of HIV transmission during labor and birth is low, so it is considered that the mother can safely breastfeed ${ }^{43}$. Although HIV-positive status is a potential contraindication to breastfeeding, there are medical as well as social reasons to encourage $\mathrm{HIV}$-positive mothers to breastfeed (provided careful monitoring).

\section{References}

1. Gertosio C, Meazza C, Pagani S, Bozzola M. Breastfeeding and its gamut of benefits. Minerva Pediatr. 2016;68(3):201-12.

2. Uvnäs-Moberg $K$, Widström AM, Werner $S$, Matthiesen AS, Winberg J. Oxytocin and prolactin levels in breast-feeding women. Correlation with milk yield and duration of breast-feeding. Acta Obstet Gynecol Scand. 1990;69(4):301-6.

\section{CYTOMEGALOVIRUS INFECTION}

Pregnant women are cytomegalovirus -positive between $37 \%$ and $93.3 \%$, and $50 \%$ of mothers produce milk with positive cytomegalovirus ${ }^{44}$. Although human milk contains biological factors that are known to protect against viral infection, inhibition of cytomegalovirus virulence is only partial and mother-to-child transmission is possible.

Lanzieri et al showed that the risk of transmission is higher in the case of fresh breast milk (19\%) compared to frozen breast milk $(13 \%)^{45}$. Another way to significantly reduce the transmission rate is by pasteurizing the milk at $62.5^{\circ} \mathrm{C}$ for 30 minutes. Because freezing or pasteurization reduces the biological and immunological value of protecting breast milk against necrotizing enterocolitis, these processes cannot be justified.

\section{CONCLUSIONS}

The decision of the mother to breastfeed, in some situations, may be a problem that requires a complex approach, being influenced in addition to contraindications of various circumstances, such as cultural characteristics, availability of care and support, as well as the feeling of security and trust in the relationship lactation. Some contraindications that were looked upon with certainty, today can be controversial. The attitude of the attending physician, whether negative or positive, may influence the mother's decision to breastfeed. The need for more research to clarify the current riskbenefit ratio regarding the contraindications to breastfeeding is highlighted.

Compliance with ethics requirements: The authors declare no conflict of interest regarding this article. The authors declare that all the procedures and experiments of this study respect the ethical standards in the Helsinki Declaration of 1975, as revised in 2008(5), as well as the national law. Informed consent was obtained from all the patients included in the study.

3. Żelaźniewicz A, Pawłowski B. Maternal breast volume in pregnancy and lactation capacity. Am. J. Phys. Anthropol. 2019; 168(1):180-189.

4. Schwartz R, Ellings A, Baisden A, Goldhammer CJ, Lamson E, Johnson D. Washington «Steps. Up: A 10-Step Quality Improvement Initiative to Optimize Breastfeeding Support in Community Health Centers. J Hum Lact. 2015;31(4):651-9. 
5. Drăghici T, Negreanu L, Bratu OG, et al. Liver abnormalities in patients with heart failure. Archives of the Balkan Medical Union, 2018;53(1):76-81.

6. Goyal RC, Banginwar AS, Ziyo F, Toweir AA. Breastfeeding practices: Positioning, attachment (latch-on) and effective suckling - A hospital-based study in Libya. J Family Community Med. 2011;18(2):74-9.

7. Stefani C, Grajdeanu IV, Serban B, Stănescu AMA. Abordarea depresiei în practica medicului de familie. Revista Medicală Română 2019;LXVI(1):24-28.

8. Toscano M, De Grandi R, Grossi E, Drago L. Role of the Human Breast Milk-Associated Microbiota on the Newborns. Immune System: A Mini Review. Front Microbiol. 2017;8:2100.

9. Telang S. Lactoferrin: A Critical Player in Neonatal Host Defense. Nutrients. 2018;04,10(9)

10. Socea B, Nica A, Bratu O, Diaconu C, Smaranda A, Socea L, et al. Incidental finding of a sigmoid intussusception associated with rectal prolapse-a case report. Archives of the Balkan Medical Union, 2018;53(1): 143-146.

11. Diaconu C, Bălăceanu ALICE, Moroşan E. Sepsis biomarkers: past, present and future. Farmacia 2015; 63(6), 811-815.

12. Stănescu AMA, Grajdeanu IV, Serban B, Bratu OG, Diaconu CC. Importanța supradiagnosticării în medicina de familie. Cum minimalizăm riscurile? Revista Medicală Română 2019; LXVI(1): 29-33.

13. Grajdeanu IV, Stănescu AMA, Stefani C, Gheorghe G, Diaconu CC. Impactul asupra mamei, fătului și nou-născutului în cazul varicelei la gravidă. Practica Medicală 2019;14,1(64):21-25.

14. Saha MR, Ryan K, Amir LH. Postpartum women.s use of medicines and breastfeeding practices: a systematic review. Int Breastfeed J. 2015;10:28

15. Diaconu CC, Dumitru N, Fruntelata AG, Lacau S, Bartos D. Apical hypertrophic cardiomyopathy: the ace-of-spades as the disease card. Acta Cardiologica Sinica 2015; 31(1), 83.

16. Arguello B, Salgado TM, Fernandez-Llimos F. Assessing the information in the summaries of product characteristics for the use of medicines in pregnancy and lactation. Br J Clin Pharmacol. 2015;79:537-44.

17. Anderson PO, Manoguerra AS, Valdés V. A review of adverse reactions in infants from medications in breastmilk. Clin Pediatr. 2016:55:236-44.

18. Diaconu CC, Balaceanu A, Bartos, D. Diuretics, first-line antihypertensive agents: are they always safe in the elderly. Rom $\mathrm{J}$ Intern Med, 2014;52(2), 87-90.

19. Rowe H, Baker T, Hale TW. Maternal medication, drug use, and breastfeeding. Child Adolesc Psychiatr Clin N Am. 2015;24:120.

20. Feldman-Winter L, Szucs K, Milano A, Gottschlich E, Sisk B, Schanler RJ. National trends in pediatricians. practices and attitudes about breastfeeding: 1995 to 2014. Pediatrics 2017; 140:e20171229.

21. Hughes H. Postpartum contraception. J Fam Health Care 2009; 19:9-10.

22. Stănescu AMA, Grajdeanu IV, Diaconu CC, Iancu MA, Stefani C. Evolutia psoriazisului prenatal, postnatal, afectarea fătului, modificări imune și hormonale, tratament. Practica Medicală 2018;13,1(54): 36-40.

23. Halderman LD, Nelson AL. Impact of early postpartum administration of progestin-only hormonal contraceptives compared with nonhormonal contraceptives on short-term breast-feeding patterns. Am J Obstet Gynecol. 2002;186:1250-6; discussion

24. Curtis KM, Tepper NK, Jatlaoui TC, Berry-Bibee E, Horton LG, Zapata LB, et al. U.S. medical eligibility criteria for contraceptive use, 2016. MMWR Recomm Rep. 2016;65:1-104.

25. American College of Radiology Committee on Drugs and Contrast Media. ACR Manual on Contrast Media. Version 10.3
(2017). American College of Radiology; https://www.acr.org/-/ media/ACR/Files/Clinical-Resources/Contrast_Media.pdf

26. McNeilly AS, Glasier AF, Howie PW, Houston MJ, Cook A, Boyle $H$. Fertility after childbirth: pregnancy associated with breast feeding. Clin Endocrinol. 1983;19:167-73.

27. Cetin I, Assandro P, Massari M, Sagone A, Gennaretti R, Donzelli G, et al. Working group on breastfeeding, Italian Society of Perinatal Medicine and Task Force on Breastfeeding, Ministry of Health, Italy. Breastfeeding during pregnancy: position paper of the Italian Society of Perinatal Medicine and the Task Force on Breastfeeding, Ministry of Health, Italy. J. Hum. Lact. 2014:30:20-7.

28. Brown A, Rance J, Warren L. Body image concerns during pregnancy are associated with a shorter breast feeding duration. Midwifery 2015;31:80-9.

29. Stefani C, Grajdeanu IV, Serban B, Stănescu AMA. Importanța cunoașterii manifestărilor cutanate fiziologice în sarcină pentru managementul corect al afecțiunilor cutanate în sarcină. Practica Medicală 2019;14,1(64):26-29.

30. Collaborative Group on Hormonal Factors in Breast Cancer Breast cancer and breastfeeding: collaborative reanalysis of individual data from 47 epidemiological studies in 30 countries, including 50302 women with breast cancer and 96973 women without the disease. Lancet 2002;360:187-95.

31. Bratu OG, Marcu RD, Socea B, Neagu TP, Diaconu CC, Scarneciu I, et al. Immunohistochemistry particularities of retroperitoneal tumors. Rev Chim (Bucharest) 2018;69(7):1813-1816.

32. Lambertini M, Kroman N, Ameye L, Cordoba O, Pinto A, Benedetti $G$, et al. Long-term safety of pregnancy following breast cancer according to estrogen receptor status. J Natl Cancer Inst. 2018;110:426-9.

33. Schiff M, Algert CS, Ampt A, Sywak MS, Roberts CL. The impact of cosmetic breast implants on breastfeeding: a systematic review and meta-analysis. Int Breastfeed J. 2014;9:17.

34. Roberts CL, Ampt AJ, Algert CS, Sywak MS, Chen JS. Reduced breast milk feeding subsequent to cosmetic breast augmentation surgery. Med. J. Aust. 2015;202:324-8.

35. Kraut RY, Brown E, Korownyk C, Katz LS, Vandermeer B, Babenko $\mathrm{O}$, et al. The impact of breast reduction surgery on breastfeeding: systematic review of observational studies. PLoS ONE 2017;12:e0186591.

36. Andrade RA, Coca KP, Abrão AC. Breastfeeding pattern in the first month of life in women submitted to breast reduction and augmentation. J Pediatr. 2010;86:239-44

37. Beshyah SA, Sherif IH, Chentli F, Hamrahian A, Khalil AB, Raef $\mathrm{H}$, et al. Management of prolactinomas: a survey of physicians from the Middle East and North Africa. Pituitary 2017;20:23140.

38. Maiter D. Prolactinoma and pregnancy: from the wish of conception to lactation. Ann Endocrinol 2016;77:128-34.

39. Fowler MG, Flynn P, Aizire J. What is new in perinatal HIV prevention? Curr Opin Pediatr. 2018;30:144-51.

40. Olariu C, Nurciu A, Vasilescu I, Stănescu AMA, Dobre C, Sticlaru L, Olariu M. Afectarea măduvei hematogene la pacienții cu infectie HIV. Practica Meicală 2018;13,2(57):156-161.

41. Bispo S, Chikhungu L, Rollins N, Siegfried N, Newell ML. Postnatal HIV transmission in breastfed infants of HIV-infected women on ART: a systematic review and meta-analysis. J Int AIDS Soc. 2017:20:21251.

42. Stănescu AMA, Grajdeanu IV, Bejan GC, Bratu OG, Kozma A, Codreanu IF, Diaconu CC. Predictia prevalentei HIV pană în anul 2022 în România și Uniunea Europeană. Revista Medicală Română 2018;LXV(4):261-265.

43. World Health Organization Guideline: Updates on HIV and Infant Feeding: The Duration of Breastfeeding, and Support from Health Services to Improve Feeding Practices Among Mothers Living with Geneva. World Health Organization; (2016). 
Ana Maria Alexandra STANESCU et al.

44. Antona D, Lepoutre A, Fonteneau L, Baudon C, HalftermeyerZhou F, Strat LE Y, et al. Seroprevalence of cytomegalovirus infection in France in 2010. Epidemiol Infect. 2017;145:1471-8.

45. Lanzieri TM, Dollard SC, Josephson CD, Schmid DS, Bialek SR. Breast milk-acquired cytomegalovirus infection and disease in VLBW and premature infants. Pediatrics 2013;131:e1937-45. 